\title{
GREEN BIM CONCEPT - SCANDINAVIAN INSPIRATIONS
}

\author{
K. ARASZKIEWICZ ${ }^{1}$
}

\begin{abstract}
This article discusses an integrated concept of sustainable building and of Building Information Modelling (BIM) by means of implementation of the Green BIM management method. Apart from presenting this innovative project management method with particular attention paid to solutions applied by Scandinavian enterprises, the article aims at analysing institutional conditions regarding application of the Green BIM within Polish construction companies. Arguments presented in the article are based on results of a scientific review and industry specific publications. Moreover, the article discusses case studies of projects completed with the implementation of the Green BIM method.
\end{abstract}

Keywords: innovations, Building Information Modelling (BIM), sustainable building

\section{INTRODUCTION}

Organisational innovations which are related to the Building Information Modelling (BIM) concept as well as sustainable building are the two crucial trends of global changes within the construction industry which have been observed and described in numerous publications in the last few years. Until recently, those changes occurred separately and independently of one another.

For several years, integration of BIM assumptions and sustainable construction principles by means of implementing the Green BIM concept has been increasingly generating interest (McGraw - Hill Construction, 2010, p. 8). Building Information Modelling is a concept which has been known and present in the western world for more than a decade now.

\footnotetext{
${ }^{1}$ PhD Eng, West Pomeranian University of Technology, Faculty of Civil Engineering and Architecture, Al. Piastów 17, 70-310 Szczecin, e-mail: krystyna.araszkiewicz@zut.edu.pl
} 
In essence, it is a process involving generating and management of digital representations of physical and functional characteristics of construction works. Management demands that BIM is not only a structure model, an IT tool or a database of structural information. Apart from 3D design, BIM implementation covers the entire concept-to-occupation time-spanandintegrating management activities pertaining to project schedules and costs (Azhar, Khalfan and Maqsood, 2012, p.17). Green BIM is emerging as a new form of project design and delivery, based on convergence of sustainable building and BIM. Ghandi and Jupp (2013) define Green BIM as being based on three conceptual pillars: (1) integrated design processes and building systems supported by object - based modelling and analysis tools, (2) environmentally sustainable design principles and (3) optimization of green buildings certification credits. The author is of the opinion that the application of BIM principles and tools in order to achieve project sustainability is an important direction of changes from the perspective of the Polish construction industry. It makes it possible to take advantage of the synergy effect and of foreign experiences related to Green BIM implementation in project management. However, it requires a fundamental change of the mindset of all the participants in the investment and construction process and a profound modification of the entire market organisation principles involving all the stakeholders. The purpose of this paper is to provide an overview of Green BIM implementation with focus on Scandinavian countries. The paper presents the process of BIM implementation in those countries, followed by a discussion on Green BIM, its applications, benefits, risks and associated challenges to the construction industry. Arguments presented in the article are based on results of a review of scientific and industry specific publications. The conclusions are reached after theGreen BIM case study is elaborated and Scandinavian experience is discussed as a source of positive practices with respect to implementation of Green BIM.

\section{BIM IN SCANDINAVIA}

Rundquist at al. (2013) indicate that integration of knowledge of all the participants in the process at the following three levels is the primary factor determining success of innovations within projects, between projects and within industrial manufacturing organisations.. Institutional support facilitates' knowledge integration has beenproven by the experiences of Finland, a country which is now an uncontested leader in the area of innovations; including the implementation of BIM. Kiviniemi (2006) indicates that problems regarding flow of information and management of communication throughout a project's lifecycle have been identified as crucial areas requiring intervention within the framework of the Finnish technology development policy developed in mid 
1990s. Implemented by the Technology Agency of Finland in the years 1997-2002, the Vera programme - Information Networking in the Construction Process - covered more than 160 projects some of which were implemented by construction companies which alsoconsidered implementation of new information technologies constituting BIM set of instruments (Kiviniemi, 2006, p. 16). The results of BIM related implementations were so encouraging from the perspective of key construction companies, that in the following years the Confederation of Finnish Construction Industries had decided to implement a new programme referred to as ProIT (Product model data in construction projects), which continued to apply the assumptions of the Vera programme. BIM guidelines were developed in the Finish construction industry in order to introduce common practice for modelling. The implementation of BIM in Finland illustrates the importance of actions undertaken by state authorities in order to initiate and 'speed up' such innovations as introduction of the BIM concept in the construction industry. Advantages resulting from BIM will depend on cooperation and knowledge integration. State institutions may undertake measures aimed at implementing BIM standards within the construction industry; they may also support research and development work undertaken by companies. This in turn may speed up the rate at which innovators gain advantages. During the subsequent stage, given the observed and experienced advantages of BIM implementation, entrepreneurs and private investors will be the active drivers of innovation. The BIM idea was applied to numerous investments, primarily public ones, in other Scandinavian countries as well. Since 2012, Norway has required application of BIM assumptions to railway and road investments; state institutions apply this requirement to public procurement proceedings pertaining to the building and extension of infrastructure. Execution of construction works, in accordance with the BIM concept has become increasingly widespread.

\section{GREening BIM}

For quite a long time now, global interest has been growing in buildings which comply with the principles of sustainability. This kind of sustainability is, interpreted as limiting the impact of civil structure on the natural environment throughout its whole lifecycle, 'from the cradle to the grave'.. This trend can also be observed in Poland, which is indicated by current results of market research and surveys regarding perception of sustainable building (Śliczna, 2011, p.380). Main features of buildings meeting sustainability criteria include energy savings and good quality of the internal environment (Construction Marketing Group 2014, p. 14). However, a sustainable building ought to meet further requirements, primarily in terms of balancing investment expenditures and operation 
costs (energy and water consumption), ensuring comfort of use and minimising impact on the environment. Sobotka and Wyatt (1998) indicate that the rules of sustainable development must refer to the building sector as a building object in its life cycle, similar to the product life cycle chain: from procurement of raw materials for the construction of a building and their evaluation to demolition of the building. Design, production and operation of structures which meet sustainability criteria require a new set of information as compared to data pertaining to conventional civil engineering structures. In the course of the traditional process, once the design is developed, data is entered into software which enables building energy efficiency analysis at each stage of its operation. Simulation programmes used for this purpose are based on structure data pertaining to thermal insulation, climate response, glazing, shading, solar gain, solar penetration, air tightness, natural ventilation, mechanical ventilation HVAC system, building dynamics and thermal mass. The set of information required for energy efficiency analysis purposes is extensive. Also, analyses of other aspects of building sustainability require plenty of comprehensive information. This results in the need to apply effective solutions offered by information technologies. The Green BIM idea integrates the structure model with simulations reflective of its impact on the environment, improving the analysis and eliminating errors of data handling (Motawa and Carter, 2013, p. 421). One of the most crucial aspects of sustainable building is an integrated approach towards construction projects which takes into account their impact on the environment and on the community throughout their lifecycle. This requires close cooperation and good communication between the investor, designers and contractors. 'Current thinking in engineering reinforces this idea in realizing that cross-disciplinary thinking and skills are key elements of sustainability' (Hyatt, 2011, p. 2). Green BIM is a concept according to which good communication and smooth exchange of civil structure related information, inclusive of information related to sustainability criteria, with the application of state-of-the-art information technologies, is the core of the investment and construction process (McKenzie, Rodriquez and McCarthy, 2013). Case studies analysed in subject literature indicate that application of the Green BIM concept is particularly advantageous with respect to those structures which are subject to certification ensuring that they meet sustainable building criteria (LEED, BREAM) and with respect to efficient energy management, primarily at the operational stage (Azhar 2010). However, Wu and Issa (2013) state, that current Green BIM practices are unsystematic and the success of individual project usually relies on a competent project team instead of deliberations based upon a well-thought-out BIM integration process. The widespread and practical application of Green BIM remains unrealized (Siddiqui et al. 2009). Given the extensive experience of Scandinavian countries with respect to 
implementation of national programmes supporting BIM development, detailed case studies from those countries might provide information of importance to construction projects management theory as well as of practical application to investors, in particular public investors, and entrepreneurs. One of the flagship investments being currently carried out in Sweden in accordance with the BIM concept and sustainability criteria is the construction of the Mall of Scandinavia, the largest shopping centre in Scandinavian countries. The project is being implemented in Stockholm, Sweden, and the investment (commenced in 2012) has been scheduled for completion in the second half of 2015. Total floor space of the shopping centre amounts to more than 100000 square metres. The project is being carried out as a 'turnkey' investment in collaboration between the general contractor Peab, Ruukki, delivering the steel structures, Strängbetong and Ramboll, which provided precast concrete structure, and several other companies. The decision on the application of BIM assumptions resulted from the scale of the investment and the need to efficiently coordinate contractors at individual stages and the flow of information among all the participants in the investment process, the investor included. BIM was present throughout the project. It was applied to the investment in question in structure visualisation, by means of IFC-based integration of approximately 200 models developed with the application of various IT tools and use of data sets as a communication platform within the project. The architect's Archicad model and designer Grontmij's Tekla foundation model created a core of the further modelling processes. On a construction site Peab used Tekla BIMsight to put together all models created with various software solutions. This makes Open BIM and choosing the file format very important. IFC was selected for combining model information, as a medium to integrate the models and to transfer the information from one software to another, and DWG for information exchange between the consultants. Given the fact that the structure is executed in stages, as the first storey was being completed, while design works regarding further storeys were being carried out, good communication among designers, contractors, the general contractor and the investor is one of the most crucial factors determining the success of the investment (Kastell, 2014). The strong co-operation among many stakeholders was also needed to evoke culture of environmental awareness through the entire building process. As a result, the Mall of Scandinavia has been recognised as one of the best performing buildings assessed under sustainable buildings standard BREEAM and it has recently achieved the Excellent BREEAM rating. Examples of investments executed in accordance with BIM assumptions and sustainability principles have been described also by Skanska, another leading Scandinavian contractor operating on the international construction market. The Puuvilla shopping and service centre located in Pore, in the south-west of Finland is yet another example of a successfully 
executed investement with the application of Green BIM.. The project was awarded a LEED Gold Certificate and the prestigious 'Best BIM Project' award at the Tekla Global BIM Awards held in 2013. Puuvilla was once a large cotton mill. The vision was to transform it into a new neighbourhood for living and working, that offers high quality facilities for retail, office space, educational activities, cultural events and government functions. Skanska was the general contractor of this project and developed it with the use of BIM in close cooperation with the investor. BIM rules were applied throughout the design and construction of the development to integrate the existing structures, manage the construction schedule and develop the complex design over time. Laser scanning was used for accurate modelling of existing structures to create a base for the design. BIM tools used in design phase for different disciplines:

- architecture: ArchiCAD,

- structure: Tekla Structures,

- MEP: MagiCAD,

- IDA Indoor Climate and Energy (IDA ICE).

The contractor applied BIM tools also on construction site during the production phase and those tools comprised of: Solibri, Tekla structures, Field 3D (used on iPads). Those tools, in the opinion of the contractor, were very helpful for communication between the various project partners, first of all enabling visualisation of the project. The BIM model of the shopping centre contains a vast amount of information about the specific materials, systems and fittings installed within the building. Therefore, it also became an important facilities management tool. The contractor also used the BIM model to minimize construction waste through the accurate procurement of construction materials. The project was designed to meet LEED Gold certification criteria. The design assumed annual energy use at around $123 \mathrm{kWh} / \mathrm{m}^{2}$. Unlike a typical Finnish shopping and service building, Puuvilla is characterised by water and energy consumption reduced by about a half. These savings in resources correspond directly with the utility bill savings. BIM technology was used to provide the basis for the energy simulations. Using BIM tools to model a project's energy performance helped to identify choices that optimize the building's life cycle energy efficiency during the early design phase, when changes could be made without incurring high cost. The BIM model of the Puuvilla is also used for facility management to validate energy consumption of the buildings. The provision of as-built information for handover improves facility management and enables the verification and enhancement of building's environmental performance. Skanska has also indicated other benefits of Green BIM, such as lower material wastage and improved hauling during construction due to better project definition, lowering the cost and environmental 
impact of construction. Lower life cycle costs and environmental impact of the building through its construction and operational phase deliver an enhanced asset value. Siddiqui et al. (2009) argue that Green BIM has the potential to lead to more sustainable projects at multiple levels, supporting sustainability assessment of facilities. Though, the main barrier for Green BIM implementation has been identified as limited analysis competences of BIM applications. Therefore knowledge on Green BIM, continuous research, development of methodology and governmental legislation are needed to enhance Green BIM adoption (Rahman, Suwal and Jäväjä, 2013).

\section{REQUIREMENTS FOR GREEN BIM APPLICATION IN POLAND}

From the perspective of the Polish construction services market, BIM is still an innovative approach although it has become a standard in Western Europe. However, there is an increasing number of publications describing BIM (Zima, 2013) and analysing benefits and risks of their implementation in Poland (Mackiewicz, 2014). For quite a long time now, it has also been a problem addressed at the scientific and industry specific conferences. On the other hand, there are no comprehensive studies or analyses regarding conditions and readiness of companies and investors to implement this concept. BIM is also addressed in discussions pertaining to public procurement proceedings regarding civil engineering investments and to amendments to legal regulations implemented with the Directive of the European Parliament and of the Council 2014/24/UE of 26 February 2014 on public procurement. In practice, however, BIM is not widely applied in Poland yet. Possible reasons for this situation include:

- no comprehensive knowledge and practical experiences related to BIM on the part of both entrepreneurs and contracting authorities representing the public sector,

- high prices of software;

- limited experience related to building modelling.

One of the most important elements in BIM projects is collaboration. Participants should create an integrated team at an early stage of the project (Zima, 2013, p.81). The ability to cooperate can be one of the difficulties, requiring a change in the culture of organisations of investors, entrepreneurs, builders, architects and all other stakeholders. Leśniak and Zima (2012) discussed a problem of cost estimation using BIM and they indicate as the biggest challenge an appropriate design of elements in a BIM model by designers, as Poland does not have any guidelines on methods and levels of detail which are required in design documentation. BIM implementation in combination with sustainable building ideas appears to be a reasonable direction for the construction industry in 
Poland. This is related to the fact that BIM as a method, a set of techniques, tools and know-how is already well-developed on the European market. Also, sustainable building and green public procurement are the subject matter of good practices available in the western markets. Consequently, such experience may be taken advantage of and adapted to Polish conditions by both companies and state institutions. Given the maturity of both concepts, combined implementation of the two may result in significant benefits due to the synergy effect. Western European countries' experience indicates the importance of state support for wide implementation of the BIM concept. According to an analysis carried out by the Polish Public Procurement Office in 2011, the average annual level of green public procurement in Poland was at around 12\%. Unfortunately, results of the analysis do not indicate the percentage of civil engineering related investments (Polish Public Procurement Office 2013, p. 24). The tools referred to in the National Action Plan regarding sustainable public procurement for the years 2013 - 2016, the use of which is to increase the number of green public procurement, do not refer to possibilities offered by the Green BIM concept, while the experience of the Western European construction market indicates that the concept makes it possible for the public procurement procedures to incorporate the environmental criteria covering the entire lifecycle of the construction project. However, provisions referring to those possibilities were included in a document defining National Intelligent Specialisations (KIS) in the section covering KIS8: intelligent and energy-efficient buildings (Ministry of Economy, 2014). The market of sustainable construction technologies and materials has developed in Poland to a level which is sufficient to implement green public procurement procedures, integrating environmental criteria in procurement subject matter description, or bid evaluation (IETU, 2006). Given the fact that the question of how to implement the concept on the Polish market with the use of the public procurement system remains open to Green BIM related surveys, contracting authorities' knowledge of Green BIM assumptions and benefits of the concept application to construction projects needs to be identified. Analyses' results of practical importance will include recommendations pertaining to institutional measures which may facilitate the process.

\section{Conclusions}

Modern trend regarding construction project management integrate two very important issues BIM-based project management and sustainable development. Building Information Modelling is a concept primarily based on effective communication among all the participants in the investment process based on modern information technologies. The solution, still innovative to the Polish 
construction industry, has already become widely applied on the Western European markets. Scandinavia is an area of numerous interesting implementations involving BIM. The experience of such Scandinavian countries as Finland or Sweden indicate the importance of policies supporting innovations in the construction industry which are implemented by state institutions with a view to BIM general application to the design, execution and operation of civil structures. Sustainable building is another area in which state support plays an important role. This support can be provided by means of a green public procurement system. BIM and sustainability are two symbiotic forces that are sweeping nowadays through the construction industry worldwide. To some extent they are achievable on their own, but maximizing the potential of any of these items requires the use of the others (Becerik-Gerber \& Kensek, 2010, p. 140). These concepts could assist an innovativeness enhancement in the Polish construction industry both at the project and enterprise levels. Green BIM application appears to be particularly interesting to the public procurement in Poland. It combines innovative investment management based on state-of-the-art IT tools and sustainable development issues. In the author's opinion, focusing policies supporting innovations in the construction industry on Green BIM is justified and primarily important because both BIM and sustainable building provide an extensive base for good practices, and combination of the two enables synergy of experience and knowledge. The article indicates the direction of further surveys pertaining to the public investor and their role in the application of Green BIM in Poland. It is an area of importance to both development of knowledge of project management and its practical application in the company's innovativeness of which, not only technological but also organisational, is of crucial importance to increasing competitiveness of the Polish construction industry.

\section{REFERENCES}

1. Construction Marketing Group „Analiza rynku zrównoważonego budownictwa w Polsce”, Buro Happold, http://www.burohappold.com/fileadmin/uploads/bh/Documents/Brochures/Analiza_rynku_zrownowazonego_ budownictwa_w_Polsce.pdf.

2. Instytut Ekologii Terenów Uprzemysłowionych (IETU), „Analiza i ocena możliwości stosowania w polskich warunkach kryteriów środowiskowych w zamówieniach publicznych”, Katowice, 2006.

3. Urząd Zamówień Publicznych, „Krajowy Plan Działań w zakresie zrównoważonych zamówień publicznych na lata 2013-2016", Warszawa 2013.

4. Rada Ministrów, KIS 8. Inteligentne i Energooszczędne Budownictwo, Warszawa 2014.

5. Skanska S.A. Sustainability case studies, 2015 [http://group.skanska.com/sustainability/our-journey-to-deepgreen/green-bim/.

6. McGraw - Hill Construction, SmartMarket Report, "Green BIM: How Building Information Modeling is Contributing to Green Design and Construction", Bedford, 2010.

7. S. Azhar "BIM for sustainable design: results of an industry survey", in: Journal of Building Information Modeling, 2(1), pp. $27-28,2010$. 
8. S. Azhar, M. Khalfan and T. Maqsood, Building information modelling (BIM): now and beyond, in: Australasian Journal of Construction Economics and Building 12 (4), pp. 15-28, 2012.

9. B. Becerik - Gerber and K. Kensek "Building Information Modeling in Architecture, Engineering and Construction: Emerging Research Directions and Trends" in Journal of Professional Issues in Engineering Education And Practice, ASCE, pp. 139 - 146, 2010.

10. S. Ghandi, J.R. Jupp, "Characteristics of Green BIM: Process and Information Management Requirements”, in: Bernard A., Rivest L. and Dutta D. (ed.), Product Lifecycle Management for Society, Springer- Verlag Berlin Heidelberg, pp. 596-605, 2013.

11. B. A. Hyatt, "A Case Study in Integrating Lean, Green, BIM into an Undergraduate Construction Management Scheduling Course", 47th ASC Annual International Conference Proceedings, Fresno, 2011.

12. M. Kastell, BIM in Mall of Scandinavia, online presentation www.youtube.com.

13. A. Kiviniemi, "Adopting Innovation: Building Information Models in the Finnish Real Estate and Construction Cluster", 12-14 March 2006, Cooperative Research Centre (CRC) for Construction Innovation, http://www.irbnet.de/daten/iconda/CIB1623.pdf.

14. A. Leśniak, K. Zima "Selected problems of cost estimating using BIM", Creative Construction Conference 2012, Budapest, Hungary, June 30-July 3 2012, pp. 389-399.

15. A. Mackiewicz, „BIM w polskim przedsiębiorstwie - zagrożenia i korzyści”, 2014,. [http://www.inzynierbudownictwa.pl/7823].

16. J. McKenzie, A. Rodriquez and B. McCarthy “Green BIM Meets Design-Build” Design and Build Conference, Las Vegas, November 4-6 2013, http://www.swinerton.com/files/MISC/2013 DBIA/DBIA GreenBIMFINAL Swinerton 11.4.13.pdf

17. Motawa and K. Carter "Sustainable BIM-based Evaluation of Buildings", in: Procedia - Social and Behavioral Sciences 74, 2013, pp. $419-428$.

18. Rahman A., Suwal S. and Jäväjä P. "Diverse approach of BIM in AEC industry: a study on current knowledge and practice", in: Proceedings of the 30th International Conference, Beijing, China, 9-12 October 2013.

19. J. Rundquist, S. Emmit, F. Halila, B.Hjort and B. Larsson, "Construction innovation: addressing the project product gap in the Swedish construction sector", in: International Journal of Innovation Science, vol.5, no.1, 2013, pp.1 - 10 .

20. M.Z. Siddiqui, A.R. Pearce, K. Ku, S. Langar, Y.H. Ahn, and K. Jacocks "Green BIM Approaches to Architectural Design for Increased Sustainability", in: Proceedings of the International Conference on Construction Engineering and Project Management, ICCEM-ICCPM 2009.

21. V. Singh, N. Gu, and X. Wang, "A theoretical framework of a BIM-based multi-disciplinary collaboration platform," in: Automation in Construction, vol. 20, no. 2, 2011, pp. 134-144.

22. M. Śliczna, "Chosen aspects of stimulating environment friendly buildings market development", in: Research Papers of Wrocław University of Economics (Prace Naukowe Uniwersytetu Ekonomicznego we Wrocławiu), 2011, pp: $374-385$.

23. A. Sobotka, D.P. Wyatt, Sustainable development in the practice of building resources renovation, Facilities, 16 (11), 1998, pp.319-25.

24. W. Wu and R. Issa „Integrated proces mapping for BIM implementation in green building project delivery”, in: N. Dawood an M. Kassem (Eds.), Proceedings of the $13^{\text {th }}$ International Conference on Construction Application of Virtual Reality, London, 30-31 October 2013.

25. K. Zima, "Integracja dokumentacji w procesie budowlanym z wykorzystaniem modelowania informacji o budynku", Budownictwo i Architektura, 12(1), 2013, pp. 77-84. 


\section{KONCEPCJA GREEN BIM - INSPIRACJE SKANDYNAWSKIE}

Slowa kluczowe: innowacje, Building Information Modelling, budownictwo zrównoważone

\section{STRESZCZENIE:}

W artykule zostały omówione nowoczesne trendy w zarządzaniu przedsięwzięciami budowlanymi ze szczególnym uwzględnieniem rozwiązań stosowanych przez przedsiębiorstwa skandynawskie. Doświadczenia Skandynawii we wdrażaniu innowacji zarówno technologicznych, procesowych jak i organizacyjnych w przemyśle budowlanym są źródłem dobrych praktyk dla polskiego budownictwa Artykuł porusza kwestie związane z koncepcją budownictwa zrównoważonego i na podstawie przeglądu literatury przedstawia możliwości holistycznego podejścia do zarządzania przedsięwzięciami budowlanymi, integrującego BIM z kwestiami zrównoważonego rozwoju. Innowacje organizacyjne w budownictwie, związane $\mathrm{z}$ koncepcją BIM i budownictwo zrównoważone to dwa kluczowe, obserwowane w ostatnich latach i opisywane w coraz liczniejszych publikacjach trendy globalnych zmian w przemyśle budowlanym. Do niedawna zmiany te następowały odrębnie, niezależnie od siebie. Od kilku lat coraz większe zainteresowanie budzi integrowanie założeń BIM z zasadami budownictwa zrównoważonego poprzez wdrażanie koncepcji Green BIM. W przekonaniu autora jest to ważny kierunek zmian z punktu widzenia innowacyjności polskiego budownictwa. Pozwala bowiem na wykorzystanie efektu synergii i doświadczeń zagranicznych związanych zarówno z wprowadzaniem BIM do zarządzania projektami jak i dotyczących zrównoważonego budownictwa. Wymaga to jednak fundamentalnej zmiany mentalności wszystkich uczestników procesu budowlano - inwestycyjnego, głębokiej modyfikacji zasad organizacji całego rynku budowlanego, z udziałem wszystkich jego interesariuszy.

W krajach skandynawskich idea BIM znalazła zastosowanie w wielu inwestycjach, przede wszystkim publicznych. Artykuł opisuje na przykładzie Finlandii działania podjęte przez władze publiczne, których wsparcie było znaczące dla zainicjowania i wdrożenia założeń BIM w budownictwie. Korzyści związane z BIM pojawiają się w warunkach współpracy i integracji wiedzy. Jeśli jeden z uczestników przedsięwzięcia budowlanego korzysta z narzędzi BIM, podczas gdy pozostali działają w oparciu o konwencjonalne rozwiązania (projekty dwuwymiarowe, odrębne procedury decyzyjne), nie zostaną spełnione założeń BIM, a tym samym trudno mówić o korzyściach. Stroną procesu, która może przełamać patową sytuację jest państwo i jego instytucje. Instytucje rządowe mogą podejmować działania zmierzające do wprowadzenia standardów BIM w budownictwie i wspierać prace badawczo - rozwojowe firm. To może przyspieszać osiąganie przez przedsiębiorców podejmujących ryzyko wdrożenia BIM wymiernych korzyści.

W artykule przedstawiony został przykład budowy centrum handlowego Mall of Scandinavia według założeń metody Green BIM. Mall of Scandinavia to największe centrum handlowe w krajach skandynawskich. Obiekt jest budowany w Szwecji, w Sztokholmie, zakończenie inwestycji (rozpoczętej w 2012 roku) zaplanowano na drugą połowę 2015 roku. Powierzchnia centrum wynosi ponad $100000 \mathrm{~m}^{2}$. Inwestycja jest realizowana według modelu ,pod klucz”, generalnym wykonawcą jest jedno z wiodących na rynku skandynawskim przedsiębiorstw budowlanych Peab.

Decyzja o zastosowaniu założeń BIM wiązała się z ogromną skalą przedsięwzięcia oraz koniecznością sprawnej koordynacji wykonawców poszczególnych etapów i przepływu informacji między wszystkimi uczestnikami procesu inwestycyjnego, włączając inwestora. BIM znalazł zastosowanie w omawianym przedsięwzięciu poprzez wizualizację obiektu (integrując w oparciu o IFC około 200 modeli opracowanych przy użyciu różnych narzędzi informatycznych), oraz wykorzystanie tego zbioru informacji jako platformy komunikacyjnej w projekcie. Z uwagi na to, że obiekt jest realizowany etapami (pierwsza kondygnacja była już budowana, podczas gdy równolegle prowadzono prace projektowe 
kolejnych kondygnacji obiektu), dobra komunikacja między projektantami, wykonawcami i generalnym wykonawcą oraz inwestorem jest jednym z kluczowych czynników decydujących o powodzeniu tej inwestycji.

Studia przypadków analizowane w literaturze przedmiotu wskazują, że zastosowanie koncepcji Green BIM przynosi korzyści szczególnie w odniesieniu do obiektów poddawanych certyfikacji stosowanej dla potwierdzenia, że budynek spełnia kryteria budownictwa zrównoważonego (LEED, BREAM), oraz w zakresie efektywnego zarządzania energią, przede wszystkim na etapie eksploatacji. Przykładami realizacji przedsięwzięć według założeń BIM i zasad zrównoważenia są inwestycje przeprowadzane przez jednego z wiodących skandynawskich wykonawców na rynku budowlanym, firmę Skanska. Taką inwestycją zrealizowaną z powodzeniem z zastosowaniem założeń Green BIM jest centrum handlowo - usługowe Puuvilla w Pori, w południowo - zachodniej części Finlandii. Obiekt uzyskał certyfikat LEED Gold oraz prestiżową nagrodę "Best BIM Project" podczas uroczystości Tekla Global BIM Awards $\mathrm{w}$ roku 2013. W porównaniu $\mathrm{z}$ typowym fińskim obiektem handlowo - usługowym, centrum Puuvilla cechuje zmniejszone o około połowę zużycie wody i energii. Ponadto podczas budowy 95\% odpadów budowlanych zostało poddanych odzyskowi. Koncepcja BIM znalazła zastosowanie w fazie projektowania i następnie podczas realizacji, między innymi poprzez integrację informacji związanych z projektem budowlanym i analizami dotyczącymi bilansu energetycznego obiektu. Uczestnicy procesu inwestycyjnego podkreślali znaczenie narzędzi BIM dla usprawnienia komunikacji w projekcie oraz wskazywali na ogromną ilość informacji, zebranych w modelu centrum, aktualizowanych $\mathrm{w}$ trakcie budowy, istotnych z punktu widzenia eksploatacji obiektu.

Celem artykułu była także wstępna analiza uwarunkowań instytucjonalnych wprowadzania koncepcji Green BIM w Polsce. Skoncentrowanie polityki wspierania innowacji w polskim budownictwie na Green BIM jest zdaniem autora zasadne i ważne. Implementacja BIM w połączeniu z zagadnieniami budownictwa zrównoważonego wydaje się być racjonalnym rozwiązaniem dla polskiego rynku usług budowlanych. Wiąże się to z faktem, że BIM jako metoda, zbiór technik, narzędzi i know - how jest już dobrze rozwinięty na rynku europejskim. Również budownictwo zrównoważone i zielone zamówienia publiczne są przedmiotem dobrych praktyk na rynkach zachodnich. Możliwe jest wobec tego korzystanie z tych doświadczeń i dostosowanie ich do polskich uwarunkowań zarówno przez przedsiębiorstwa jak i instytucje państwowe. Z uwagi na dojrzałość obu koncepcji, wprowadzanie ich łącznie może przynieść znaczne korzyści ze względu na efekt synergii. Wśród narzędzi, wskazanych w Krajowym Planie Działań w zakresie zrównoważonych zamówień publicznych na lata 2013 - 2016, których wykorzystanie ma przynieść wzrost liczby zielonych zamówień publicznych, nie ma żadnej wzmianki o możliwościach, jakie wiążą się z koncepcją Green BIM. Tymczasem jak wynika z doświadczeń na rynku budowlanym w Europie Zachodniej, koncepcja ta umożliwia na wprowadzenie do zamówień publicznych kryteriów środowiskowych obejmujących cały cykl życia przedsięwzięcia budowlanego.

Artykuł wskazuje na kierunek dalszych badań, dotyczących inwestora publicznego i jego roli w implementowaniu założeń Green BIM. Zagadnieniem otwartym dla badań związanych z Green BIM jest sposób wdrożenia tej koncepcji na rynku polskim z wykorzystaniem systemu zamówień publicznych. Identyfikacji wymaga znajomość wśród zamawiających publicznych założeń Green BIM i posiadanie przez nich wiedzy o korzyściach związanych z zastosowaniem tej koncepcji w przygotowaniu i realizacji inwestycji budowlanych. Jest to obszar istotny dla rozwoju wiedzy o zarządzaniu przedsięwzięciami oraz jej praktycznej aplikacji na rynku usług budowlanych, których innowacyjność, ma decydujące znaczenie dla podnoszenia konkurencyjności polskiego budownictwa. 